\title{
The Middle East in International Relations: Power, Politic, and Ideology
}

Fred Halliday, Cambridge Press, 2006, 374 sayfa,

\section{Hazırlayan: Muharrem EKŞi்}

Ortadoğu'nun Uluslararası İlişkilerinin; devletlerarası savaşlar, dış müdahaleler, siyasi karışıklık, etnik şiddet ve Arap-İsrail çatışması/barış süreci, silahlanma, petrol, demokratikleşme ve radikal İslami hareketler eksenlerinde gelişme gösterdiği gözlenmektedir. Bütün bunlar Ortadoğu'nun Uluslararası İlişkilerini şekillendirerek bölgede bir belirsizlik ve çatışma ortamına zemin hazırlamaktadır. $\mathrm{Bu}$ anlamda elimizdeki bu eser, Ortadoğunun Uluslararası İlişkilerini anlama ve anlamlandırmada önemli bir başucu kaynağıdır denilebilir.

Uluslararası İlişkilerde Ortadoğu, Güç, Politika ve İdeoloji adlı dört bölümden oluşan eser, Ortadoğu Uluslararası İlişkileri'ni ve Ortadoğu'nun oluşumunu, hem küresel hem de bölgesel bağlamda, tarihsel derinliği ve perspektifiyle, kuvvetli bir analiz sunmaktadır. Yazar, üç aşamalı bir analiz yöntemini kullanmayı tercih etmiştir. Buna göre birinci aşamada bölgenin dış dünya ile ilişkileri, ikinci aşamada ulus-devletler arasındaki bölge içi rekabet ve son olarak da münferit olarak toplumlarda etnik ve sınıf çatışmalarını irdelemektedir. Bu anlamda bu metodolojik yaklaşımıyla eserin, Uluslararası İlişkiler disiplinine yeni bir boyut getirdiği ileri sürülebilir. Bu anlamda yazarın bu alandaki diğer çalışmalara nazaran tarihsel arka plana ağırlıklı olarak yer vermesiyle tarihsel derinliğe en fazla önem veren yazarlardan biri olduğu söylenebilir. Zaten yazarın bu kitabı yazma amacının, bu alanda yazılmış olan diğer eserlere ve bu eserlerin yaklaşım tarzlarına bir meydan okuma olduğu, yazar tarafindan da ifade edilmektedir. Bu doğrultuda yazar, Ortadoğu araştırmalarında Oryantalist bakış açısına, bölgeyi dünyadan soyutlayan araştırma biçimine, bölgeyi tek bir faktörle açıklama metoduna ve tarihsel indirgemeciliğe karşı çıkmaktadır. Ayrıca yazarın kırk yıllık birikimi ve engin tecrübesi, Ortadoğu alanındaki eserlere ve konulara vukufiyeti, çalışmanın analiz bölümlerinde ve kaynak taramasında açıkça anlaşılmaktadır. Bununla birlikte eser, Ortadoğu politikası ve Uluslararası İlişkileri'ne bir giriş mahiyetinde olup, analitik bir çalışma sunmaktadır.

* Ankara Üniversitesi, Küresel ve Bölgesel Çalışmalar Anabilim Dalı, Yüksek Lisans Öğrencisi. 
Giriş bölümünde, Ortadoğu'nun dünya politikasında dört büyük çatışma alanından biri olduğunu vurgulayan yazar, Ortadoğu Araştırmaları bölümlerinde Ortadoğu'nun genellikle İslami yani dini perspektiften sunulduğunu; buna karşılık kendisinin bakış açısını, dil üzerine temellendirdiğini önemle vurgulamaktadır. Bu anlamda yazar, dil bilgisinin kendisine o ülkenin politikasını ve kimliğinin bilgisini sunduğunu ve Ortadoğu'ya dil, tarih ve uluslararası İlişkiler perspektifinden baktığını ve eserini, bu bakış açısı çerçevesinde şekillendirdiğini belirtmektedir.

Birinci bölümde, beş farklı yaklaşımla Ortadoğu Uluslararası İlişkilerinin tarihsel analizini yapan yazar, tarihsel perspektifin bölgenin analizi için temel olduğuna işaret etmektedir. Bu bağlamda, realizm, sistem ve devlet paradigmalarını kullanarak tehdit algılamalarını değerlendirerek; daha önceki akademik literatürde Ortadoğu Uluslararası İlişkileri'nin sadece sistematik, küresel ve stratejik yönlerinin argüman yapıldığını ve böylece bölgenin sadece 19. yüzy1l güçler dengesi, Osmanlı Devleti'nin gerilemesi, Sömürgecilik, Dünya Savaşları ve Soğuk Savaş terimleri açısından ele alındığını tespit eden yazar, bu sistematik yaklaşıma meydan okumaktadır. Ayrıca yazar, Ortadoğu literatüründe İslam-Batı, Doğu-Batı ve İdeoloji çatışması gibi kültürel anlatım tarzının, Ortadoğu'nun İslam ile özdeşleştirildiği bir metodolojik sapmaya dikkat çekmiş ve bu durumun fikir bazlı yaklaşım tarzının bir ürünü olduğunu ileri sürmüştür. Gerçekten de Ortadoğu'nun yüzeysel kavramsallaştırmalara maruz kaldığı gerçeği, yazarın dikkatinden kaçmamıştır. Bununla birlikte yazar, tarihsel sosyolojik yaklaşımıyla, bölgenin paylaştığı politik kültürü analiz etmeye çalışmıştır. Böylece yazarın, Ortadoğu Uluslararası İlişkileri'ni anlama, anlamlandırma ve kavramada tarihsel sosyolojiyi temel aldığı söylenebilir.

Diğer taraftan Uluslararası İlişkilerde Ortadoğu, bölgesel devletlerin ve bunların birbiriyle ve diğer bölge devletleriyle ilişkilerinin bir yansıması şeklinde tanımlanmıştır. Ayrıca Ortadoğu devletlerinin devlet formasyonları ve bu devletlerin kendi otoritelerini meşrulaştırırken kullandıkları tarihsel ve özellikle ideolojik argümanlar detaylı bir şekilde analize tabi tutularak Ortadoğu'daki güç, politika ve ideolojiler tanımlanmaya çalışılmıştır. Yapısal bağlamda ise Ortadoğu devletlerinin uluslararası yapısal sisteminin zayıf olduğu ve stratejik derinlik açısından ise devlet ve coğrafya arasında bir uyumsuzluk problematiğini ortaya koyan yazar, bölgenin paradokslarından birinin de liderlik modelinden kaynaklandığını ileri sürmektedir. Bununla birlikte Ortadoğu politikasına hâkim ideolojileri analiz etmenin yanında yazar, Ortadoğu Uluslararası İlişkileri'nin hem içsel çeşitlilikten hem de dışsal faktörlerden etkileşimle oluştuğunu belirtmiştir. Bu açıdan yazar, Or- 
tadoğu Uluslararası İlişkileri'ni büyük devletlerin kontrol ettiğine dair tezi de çürütmeye çalışmıştır.

İkinci bölümde Ortadoğu'da devlet yapılanmasının analizi ve Ortadoğu oluşumunun tarihsel sürecini derinlemesine inceleyen yazar, strateji bağlamında Ortadoğu'nun 20. yüzyılda içsel ve dışsal faktörlerin dengesinde ve korelasyonu çerçevesinde şekillendiğini vurgulamıştır. Ayrıca, bölgenin bu yüzyılda küreselleşme olgusu ile bölgesel manevra ve küresel rekabet arasındaki ilişkiyi, yazar asimetrik bir biçimde analiz etmiştir. Diğer taraftan, yazar 20. yüzyıldaki uluslararası sistem ve jeopolitik_değişimin bölgesel sonuçlarını çıkarıp, bunların Oratdoğu'yu nasıl şekillendirdiğini ve bölgedeki etkilerini etkileyici bir tarzda değerlendirmiștir. Bu bağlamda, bu yeni bölgesel şekillenmeyle birlikte, küresel güç ABD'nin bölgeyle ve bölgesel güçlerle oluşturduğu stratejisi, küresel süreçte bölgesel gelişmeler açısından incelenmiştir. $\mathrm{Bu}$ anlamda, yazar ABD'nin bölgede tarihsel derinlikten yoksun olduğunun, yani bölgede Sovyet mirasına sahip Rusya gibi etki araçlar1na sahip olmadığının altını çizerek bu yeni stratejik oyun sahnesini izah etmektedir.

Ayrıca, Ortadoğu'da küreselleşme ve küresel sürecin devreye girmesiyle, "Great West Asian Crisis" yani "Büyük Batı Asya Krizi”ni kavramsallaştıran yazar, buradan hareketle Ortadoğu'nun politik fenomeni olan bölgesel iç çatışmanın yerini, küresel düzeyde "Uluslararası Terörizm"e bıraktığını belirtmiştir. Bunun sebebinin de aslında radikal İslami hareketlere karş1 yeni bir konjöktürün Ortadoğu'yu etkileyerek şekillendirdiğini ortaya konulmuştur. Bununla birlikte Batı'nın aslında İslam'1 tehdit olarak algıladı$\breve{g} 1$, hâlbuki buna gerek olmadığı ve eğer tehdit algılanacak bir durum veya meydan okuma varsa bunun Ortadoğu'daki zayıf devletlerden değil, Doğu Asya ve AB'den gelen ekonomik meydan okumasinın daha anlamlı olur değerlendirmeleri gerçekten dikkate şayandır.

Üçüncü bölümde, Ortadoğu'da Uluslararası İlişkiler boyutlarını ele alan yazar, Ortadoğu Uluslararası İlişkileri ve Politikası'nın özelliklerini, devletlerarası çatışmalar, askeri darbeler, iç savaşlar, gerilla savaşları ve terörizm şeklinde tanımlamaktadır. Buradan hareketle, çatışma ve savaşların Ortadoğu'da Uluslararası İlişkilerin çerçevesini çizdiği genellemesi yapılmıştır. Bunun da en önemli sebebinin, bölgede Avrupa'daki gibi bir güvenlik ve işbirliği mekanizmasının olmayışına bağlamaktadır. Hâlbuki bölgede çok fazla etkili ve yaptırım gücü olmasa da bir işbirliği teşkilatı olarak İslam Konferansı Örgütü (IKÖ) bulunmaktadır. Fakat bunun da bir yaptırım gücü olarak bir barış gücü olmayışı -bugünlerde artık bu konu İKÖ içinde tart1şılmaktadır- çatışmaları engelleyememektedir. 
Diğer bir farklı açıdan Ortadoğu'da barış alternatifleri yerine, daha ziyade çatışma alternatiflerinin bulunduğu ve bu unsurun bölge politiğine yerleştiği değerlendirilmesi, yazarın tarihsel bakış açısının bir paradigmasıdır denilebilir. Ayrıca, Uluslararası ekonomi politiğinin, Ortadoğu'nun formasyonu üzerindeki etkileri analiz edilerek, bu ekonomi politiğin Ortadoğu ekonomisinin dünya pazarıyla entegrasyonunu engellediği gibi; bölgesel kalkınmaya da katkı yapmadığı, tam tersine bölgsel çatışmaları artırıcı bir etki yaptığı tezini savunulmaktadır. Bunun esas sebebinin bölgede ticaretin siyasallaştırılması olduğu ise son derece isabetlidir.

Sonuç bölümünde yazar, Ortadoğu Uluslararası İlişkileri'ni uluslararası perspektifte hem küresel hem de bölgesel bağlamda ele almıştır. Bu açıdan yazar, bu eserin Ortadoğu Uluslararası İlişkileri çalışmalarına meydan okuduğunu, uluslararası ilişkiler teorileri açısından, bölgenin nasıl anlaşıldığını ve bu teorilerin Ortadoğu'yu anlatmaya yardımcı olamayacağını iddia etmektedir. Bu bağlamda yazar, teorik yaklaşım yerine tarihsel perspektifi sunarak eserinde dört tez ileri sürmüştür. Bunlardan birincisi, bölgenin küresel, bölgesel ve ekonomik sistemine, tarihsel perspektiften bakılması gerektiği savıdır. İkincisi bölgede farklı entegrasyonların, kurumsal ve hukuksal konseptin olduğudur. Üçüncüsü küresel güç yapılanması etkileşiminde bölgesel devletler yaklaşımıdır. Dördüncüsü devlet-dışı sosyal hareketlerin, inanç sistemlerinin, ideolojilerin ve bölgenin normlarının incelenmesi gerektiği savlarını ileri sürmektedir. Ayrıca bu alternatiflerin Ortadoğu Uluslararas1 İlişkileri'ni anlamada merkezi kategoriler olduğunu iddia etmektedir. Bununla birlikte, Ortadoğu'nun dünyanın hali hazırdaki en istikrarsız bölgesi olduğu da vurgulanmıştır. Bunun da en mühim sebeplerinin bölgenin militarize edilmesi, silahlanma ve dünya ekonomisiyle bütünleşme problemleri olduğu ileri sürülmüştür.

Diğer taraftan küreselleşmenin bölgede katılım, uzlaşma ve kınama olmak üzere üç farklı tepki oluşturduğunu belirtmektedir. Ayrıca yazar, Ortadoğu'nun dünya politikasının merkezi ve ekseni olduğunu, fakat analizlerde bunun belirtilmediğini; buna karşın analitik ve stratejik çeşitliliği sunarak, Ortadoğu Uluslararası İlişkileri’nde tek bir merkezin olmadığını iddia etmektedir.

Sonuç olarak, Fred Halliday, Ortadoğu Uluslararası İlişkileri'ne dair otoriter bir analiz sunmaktadır. Bu eserin amacı, Ortadoğu Uluslararası İlişkilerini, politikasını ve bölgenin karakterini, formasyonunu tarihsel bir perspektiften sunarak analiz etmektir. Kırk yıllık birikimiyle eserini oluşturan yazar, bir nevi bölgenin uluslararası ilişkiler tarihini de yazmaktadır. Bununla birlikte eser politik, ideolojik, askeri, ekonomik ve sosyal açılardan çok 
boyutlu analize tabi tutulmuştur. Böylece bu eserin önemi, Ortadoğu Uluslararası İlişkileri'ni anlama, anlamlandırma ve yorumlamada alternatif bir bakış açısı sunmasıdır. Uluslararası İlişkiler literatürüne önemli bir katkı sağlayan eserde, ileri sürülen tezlerin birçoğuna katılmak mümkündür.

Ancak Ortadoğu’yu ekonomi politik bakımından ele aldığı bölümde, enerji faktörünün Ortadoğu Uluslararası İlişkilerini nasıl şekillendirdiği veya etkilediği konusuna değinilmemesi; ekonomi politik açıdan Ortadogu'nun dünya ekonomisiyle bütünleşmesinin sadece petrol rezervlerine indirgenmesinin eserin en önemli eksikliklerinden biri olduğu ileri sürülebilir. Dolayısıyla bu kitap, tarihsel derinliği ve kapsamlı araştırması ile hem bilim adamlarına, ögrencilere ve hem de genel olarak konuyla ilgilenen okuyucu kitlesine de hitap etmektedir. 


\section{DÜZELTME}

Dergimizin Cilt 2, Sayı 1, 2007 sayısında Sayfa 179'daki tablo 3, baskı hatasından dolayı eksik çıkmıştır. Düzeltilmiş şekli aşağıdadır.

Tablo 3: Cari Fiyatlarla Gayrisafi Yurtiçi Hâsıla (1999-2005) (1000 Milyon avro)

\begin{tabular}{|c|l|l|l|l|l|l|l|}
\hline Ülkeler/Yıllar & 1999 & 2000 & 2001 & 2002 & 2003 & 2004 & 2005 \\
\hline AB-25 & 8484 & 9092 & 9458 & 9811 & 9961 & 10432 & 10817 \\
\hline AB-15 & 8152 & 8711 & 9129 & 9357 & 9511 & 9946 & 10264 \\
\hline AB- Parasal Birlik & 6376 & 6711 & 7000 & 7246 & 7454 & 7751 & 7999 \\
\hline Japonya & 4082 & 5037 & 4571 & 4147 & 3745 & 3690 & 3672 \\
\hline ABD & 8696 & 10629 & 11309 & 11072 & 9699 & 9699 & 10037 \\
\hline
\end{tabular}

Kaynak: Eurostat Yearbook 2006-2007. 